\title{
Concern and anger greet shift of UK science unit into industry agency
}

London. Britain's scientific community experienced a mixture of bemusement and anger last week after a series of top-level government changes announced by John Major, the prime minister, in the immediate aftermath of his successful re-election as leader of the Conservative Party.

At the centre of the changes has been Michael Heseltine, previously president of the Board of Trade, and as such, head of the Department of Trade and Industry (DTI). $\mathrm{He}$ has been promoted to deputy prime minister in recognition of his support for Major's successful re-election.

Heseltine, who has long argued for science to be integrated into industrial and economic policy, will have broad-ranging powers in his new post. These will, in particular, include the chairmanship of the cabinet's science and technology subcommittee, made up of all cabinet ministers with an interest in research.

He will also take with him to the Cabinet Office members of the DTI's team concerned with the international competitiveness of British industry, responsible for a white paper on the topic published two months ago in conjunction with the results of the government's technology foresight exercise (see Nature 375, 265; 1995).

But at the same time, the Office of Science and Technology (OST), which is responsible for the work of Britain's seven research councils, will move in the opposite direction. Set up three years ago by Major within the Cabinet office as part of the Office of Public Service and Science, the OST is now being shifted to the DTI.

As a result, Britain's £1.2-billion (US\$1.9billion) annual science budget will now become the direct responsibility of Heseltine's successor, Ian Lang. So, too, will the OST's formal role in co-ordinating the research and development activities of all government departments.

The move provoked an immediate outcry from parts of the scientific community, which had been hoping for a period of stability after the upheavals that followed the white paper of May 1993. Many scientists claim that allocating responsibility for science policy to a government department concerned primarily with promoting industrial innovation is likely to increase the difficulties of securing support for long-term fundamental research.

There is also concern that the move will inevitably undermine efforts over the past three years to use the OST's central position within the Cabinet Office to increase the impact and awareness of science in all spheres of government activity.
"The big danger is that we are back to the situation where science and technology, which should be part of across-the-board policy in government, are reduced to a junior role in another ministry with very much larger responsibilities," says Denis

\section{IMAGE \\ UNAVAILABLE FOR COPYRIGHT REASONS}

Spot the minister: lan Lang (right) will be responsible for science, but Michael Heseltine (left) will wield influence from the centre.

Noble, professor of cardiovascular physiology at the University of Oxford, and cofounder of the group Save British Science.

The concerns of scientists were only increased by a press release from Downing Street. This justified the move on the grounds that it "will allow the government's policy on science, engineering and technology to be developed alongside its policies on industry, and with due regard to the contribution of science, engineering and technology to long-term wealth creation."

Many were quick to point out, for example, that this statement makes no reference to a complementary goal which has - at least up to now - accompanied statements of the government's strategy for science, namely that it should also contribute to the quality of life. And that, even with the qualification 'long-term', it seems to suggest that research policy will in future be dominated by the needs of British industry.

"This is one step that the government will come to regret bitterly" predicts David a Triesman, general secretary of the Association of University Teachers, the body which represents the interests of academic staff. "Reducing science merely to a hand servant of industry is madness."

Government officials have been playing down the implication of the shift by emphasizing that the OST will still operate as a single unit within the DTI. They also emphasize that Robert May, who is about to take over as the head of the office, will still be chief scientific adviser to the government, with direct access to the prime minister.

In an attempt to allay concerns, Sir John Cadogan, director-general of research councils, has written to the heads of all the research councils, pointing out that the functions of the OST - including the budgets of the research councils - will be "ringfenced" within the DTI, and that he will still report directly to the cabinet minister formally responsible for science, now Lang.

In his letter, Cadogan also points out that the OST will continue to exercise responsibility for activities such as the Technology Foresight programme and the LINK programmes. "The message therefore is business as usual for the OST", wrote Cadogan.

Some scientific bodies have been cautious in their response. An official at the Royal Society, for example, said that the society was taking time to consider how it was going to react, and that it wanted to see the

\section{Parliamentary scrutiny set to fall}

London. One of the side-effects of last week's decision by the British government to merge the Office of Science and Technology (OST) into the Department of Trade and Industry (see above) is likely to be a reduction in the Parliamentary scrutiny of science policy decisions.

In particular, the move could mean the disappearance of the House of Commons Select Committee on Science and Technology, the committee which currently holds broad oversight responsibility for government decisions related to science.

It may also lead to the disappearance of the protected spot which science issues have, for the past few years, enjoyed during question time in the House of Commons, which allows Members of Parliament (MPs) to quiz the minister for science in person on topics of their choice.

Since 1979, the responsibilities of select committees have been aligned with individual government departments. This initially meant that science - which had previously enjoyed its own committee was lumped with education and the arts under the committee overseeing the Department of Education and Science.

The creation of the OST in the wake of the 1992 election meant that, for the first time in thirteen years, science and technology had their own dedicated select committee. Under the chairmanship of Sir Giles Shaw, Conservative MP for Pudsey, this has actively pursued a number of wide-ranging inquiries.

The most recent has been a 12 -month investigation, including numerous $D$ 
$\checkmark$ details of the new arrangements rather than passing any hasty judgement.

But others have greeted Cadogan's statement with scepticism, pointing out that there is little in the DTI's recent track record to suggest it is genuinely committed to longterm fundamental research. Many have been quick to point out, for example, that since the publication of the white paper on science in May 1993, the research and development budget of the department has fallen substantially.

Admittedly, much of the reduction has taken place in technology development programmes, rather than basic research, and the DTI has built strong links with various research councils, in particular the Engineering and Physical Sciences Research Council. But the department, under Heseltine's leadership, also abolished the post of chief scientific adviser shortly after the publication of the white paper.

"We note that the OST is going to be ring-fenced within the DTI, but it will be a ring fence in the middle of a lion compound," says Alun Jones, chief executive of the Institute of Physics. "It makes sense for science to be linked closer to technology and industry. But we are disappointed that it appears to have moved lower down the government's priorities."

Unsurprisingly, the decision to move the OST into the DTI has come under fierce criticism from the opposition Labour Party, which itself considered - but rejected proposing such a move as part of its own science policy two years ago. John Battle, Labour's science spokesman, says that the move represents "the demotion of science and technology".

Meanwhile in the scientific community itself, perhaps the greatest immediate concern is over the future of governmentfunded laboratories owned and run by the research councils.

Although moves to 'privatize' organizations such as the Medical Research Council's Laboratory of Molecular Biology in Cambridge had previously been headed off, the appointment of Heseltine, a keen advocate of this strategy, suggests that such proposals are likely to come in for renewed attention.

David Dickson

$D$ hearings as well as a visit to the United States, of the implications of human genetics. Its report, due next week, is expected to contain a wide sweep of recommendations, from amendments to patent legislation limiting the scope of patents on human genes, to the need for regulations on the use of genetic information by insurance companies.

If Parliament follows its established rules of procedures - and rejects moves currently under consideration to depart from its accepted practice - all such issues will now be dealt with by a committee whose main brief will be to look at all the activities of the DTI, ranging

\section{US may drop federal support for families of researchers}

San Francisco. The Clinton administration has proposed eliminating rules that allow research universities to put the relatives of faculty members through college at the taxpayer's expense. Universities say that they need the benefit in order to attract and retain top researchers. But critics say the government gets nothing in return.

According to the General Accounting Office (GAO) - the investigatory arm of Congress - between 1991 to 1993, four top US research universities charged $\$ 17$ million to the government for the tuition costs of faculty family members. The GAO studied five institutions: the Massachusetts Institute of Technology, Stanford University, the University of California, John Hopkins University and the University of Chicago.

MIT charged the highest portion -56 per cent - of its programme costs of $\$ 12,566$ per family member to federal research contracts and grants. The University of Chicago, which has the most generous programme, charged the least, with 15 percent of its $\$ 16,842$ in costs repaid by the government. The University of California asked for no reimbursement; it does not provide financial assistance to relatives of faculty, on the grounds that its tuition charges are comparatively low.

The GAO found that education benefits had been a long-standing tradition at the universities since the 1960s. The practice was initially intended to help overcome a shortage of scientists, engineers and other researchers, says Charles Thompson, assistant director in acquisition policy, technology and competitiveness issues for the GAO. "Today, the environment may be different," he adds, pointing out that the GAO did not recommend that the programme should be suspended - merely that it should be examined more closely.

Universities say the benefit remains an important recruiting tool as the salaries they offer continue to lag far behind those in the

from the management of pension funds to the operation of frontier customs. Furthermore, any questions to ministers on science-related topics could now end up being handled by a junior minister within the DTI.

Both moves have already raised concern among professional bodies such as the Royal Society of Chemistry which have grown to appreciate the opportunity that the existence of the science select committee - as well as that of a protected 'science questions' time - has provided them and others to air opinions and grievances in a formal parliamentary setting.

D. D. commercial sector. They argue that the government should allow universities to manage their overall compensation programmes, as long as the total amount of money is reasonable. Cutting the government reimbursement policy would only force them to offer higher salaries which would then be charged back to grants, universities add.

But the Clinton administration, after one look at the GAO report, proposed the reimbursement be slashed. "It was our judgment there wasn't any real benefit coming back to the government itself," says Lawrence Haas, associate director for communications at the Office of Management and Budget. He said universities may need the benefit, but that doesn't mean the government should have to pay for it.

Haas said his office would carefully consider the 200 or so responses it had received and was planning to issue a final decision within a couple of months. Sally Lehrman

\section{France urged to set up genetics network}

Paris. France's healthcare system has failed to adapt adequately to advances in genetics research, and urgently needs to create a national network of specialized genetic clinics staffed by physicians trained in medical genetics.

These are the main conclusions of a report submitted last week to Elisabeth Hubert, the minister of health, by JeanFrançois Mattei, who is both head of the Paediatrics and Medical Genetics Department at the Timone hospital in Marseille, and a member of the National Assembly (UDF, Bouches-du-Rhône).

The report claims that consultations in clinical genetics are haphazard, and are often only available from research groups at major teaching hospitals. Indeed, Mattei points out that medical genetics was not recognised as a speciality until a law making it one was passed earlier this year.

To address these deficiencies, Mattei recommends that one clinical genetics centre be set up for every 300,000 inhabitants. Each centre would include a clinical geneticist, a cytologist, and a molecular biologist.

Mattei argues that such a network will also help to regulate the development of medical genetics, and in particular avoid the setting up of private centres offering genetic testing. Support for his recommendations is likely to come from the government. Alain Juppé, the new prime minister, called for a national programme in medical genetics in a speech made shortly after his nomination in May.

Declan Butler 